\title{
Adult and Torted Juvenile Granulosa Cell Tumour
}

\author{
Bhobem D, ${ }^{1}$ Parveen S, ${ }^{1}$ Hamamy EEl, ${ }^{1}$ Maulik TG ${ }^{2}$ \\ 'Nevill Hall Hospital, ${ }^{2}$ Prince Charles Hospital, UK
}

\section{DEAR EDITOR,}

Recently we were involved in the management of 2 cases of Granulosa cell tumour one Juvenile other Adult granulosa cell tumour worth of mentioning, because of the rarity of the conditions and also because one had torsion.

\section{Juvenile Granulosa Cell Tumour}

A17year old and known case of polycystic ovarian disease (PCOD) on dianette presented with acute abdominal pain and vomiting. On vaginal examination, left sided pelvic mass tender to touch was palpated. An urgent ultrasound done reported a normal uterus and a large $8 \mathrm{~cm}$ cysticsolid mass. There was no ascitis. CT scan and tumour markers were normal. At laparotomy a $9 \mathrm{cms}$ left ovarian cyst with a solid area, twisted twice on its pedicle was seen. The cyst was enucleated preserving same side tube and contralateral right tube/ovary which were normal. Histopathology confirmed Juvenile GCT.

\section{Adult Granulosa cell tumour}

A 34 year old mentally retarded women menopause at the age of 32, on CT abdomen and pelvis, showed a soft tissue mass in the pelvis closely adherent to uterus. At laparotomy there was a solid right ovarian cyst $3 \times 4$ inches in diameter adherent to the uterus posteriorly and to the broad ligament. Uterus, tubes and left ovary were normal. There was no evidence of ascites.Total abdominal hysterectomy and bilateral Salpingo-oophorectomy was done TAHBSO with histopathology confirmation.

Granulosa cell tumors of the ovary belongs to sex cord stromal tumour, a malignant tumour with an incidence of $1-2 \%$ of all ovarian tumours but because they are so rare, in a decade period, their number were hardly counted

to 16: one case of juvenile type and 15 adult types and Adult ones are more common constituting $95 \%$ of all granulosa cell tumours and rest $5 \%$ are juvenile. They were seen in $19 \%$ nulliparous and $31 \%$ menopausal women. ${ }^{1}$ Mean tumor size is usually $10.5 \mathrm{~cm}$ with a solido-cystic aspect in $50 \%$ of cases. It essentially is a unilateral tumor that is why adolescent with Juvenile granulose cell tumour can benefit from unilateral resection. Unilateral resection as an approach may also be applied in sex cord cell tumour complicated by torsion. ${ }^{2}$ Usually these granulosa cell is believed to have low malignant potential, locally confined and rarely metastasizing to distance with recurrence only after 2-3 decades from initial diagnosis. But both forms have been to be aggressive. ${ }^{1,3}$ Inhibin secreted from grnulosa cell has been used as tumour marker to monitor the recurrence, but should not be used to screen for the presence of these tumours. ${ }^{4}$

Although they mainly secrete oestrogen and are responsible for endometrial hyperplasia, atypical hyperplasia, and endometrial cancer, both of these features were not seen in both the cases. A characteristic of granulosa cells is grooved nuclei which is pale besides presence of Call Exner bodies, which is pathognomic of the tumour.

\section{REFERENCES}

1. Savic D, Stankovic ZB, Djukic M, Mikovic ZD, Juricic S. Torsion of malignant ovarian tumors in childhood and adolescence. J Pediatr Endocrinol Metab. 2008 Nov;21(11):1073-8.

2. Taira Y, Hirakawa M, Nagayama C, Ikemiyagi K, Touma T, Tokashiki MJ. Successful treatment of adult-type granulosa cell tumor of the ovary by palliative radiotherapy. Obstet Gynaecol Res. 2011 Dec 19;doi: 10.1111/j.1447-0756.2011.01715.x. [Epub ahead of print]

3. Ellouze S, Krichen-Makni S, Trabelsi K, Ayadi L, Sellami A, Khabir A, et al. Granulosa-cell tumor of the ovary: Report of 16 cases. J Gynecol Obstet Biol Reprod (Paris). 2006 Dec;35(8 Pt 1):767-72.

4. Ala Fossi S L, Aine R, Punnonen R, Maenpaa J. Is potential to produce inhibin related to prognosis in ovarian granulosa cell tumours? European Journal of Gynaecological Oncology.2000;21(2);187-9.

\section{CORRESPONDENCE}

Dr. Sajitha Parveen, MD

Department of Obstetrics and Gynaecology

Nevill Hall Hospital, Abergavenny

South Wales, UK, NP7 7EG.

Email: sajithariaz@hotmail.com 